\title{
The investigation of correlation among selected biochemical parameters and vital signs in dairy herd to design the bio-cybernetic dairy cow model
}

\author{
J. Twardoń1 ${ }^{1}$ W. Zalewski ${ }^{4}$, T. Nowicki ${ }^{3}$, B. Dębski ${ }^{2}$, G. Dejneka ${ }^{1}$, \\ J. Mrowiec ${ }^{1}$, K. Zalewski ${ }^{2}$ \\ ${ }^{1}$ Faculty of Veterinary Medicine, Wroclaw University of Environmental and Life Sciences, \\ Norwida 31, 50-375 Wrocław, Poland \\ ${ }^{2}$ Faculty of Veterinary Medicine, Warsaw University of Life Sciences - SGGW, \\ Nowoursynowska 166, 02-787 Warsaw, Poland \\ ${ }^{3}$ Cybernetics Faculty, Military University of Technology, Kaliskiego 2, 00-908 Warsaw, Poland \\ ${ }^{4}$ University Centre for Veterinary Medicine of Jagiellonian University and University of Agriculture in Kraków, \\ Al. Mickiewicza 21, 31-120 Kraków, Poland
}

\begin{abstract}
The paper presents investigations of the relationship between the biochemical parameters and vital signs in dairy cows. We analyzed the welfare and functioning of a dairy herd using biochemical parameters and vital signs. Life and biochemical parameters were examined. In the model indicators useful for monitoring the herd are: the age of the cows, the number of cows' lactating, daily amount of received milk, length of lactation period for cows in the herd, the length of inter-calving period for cows, the number of days to effective insemination, the amount of protein in the feed, the level of $\beta$-oxidation in leucocytes, glucose transport through red blood cells and plasma insulin. Based on the results the mathematical model was designed allowing the presentation of a cybernetic model of cow's organism. There was constructed a multi-equation model which determined the relationships between the selected variables describing the state of dairy cows in the herd and variables that characterize their welfare with its statistical verification.
\end{abstract}

Key words: cow, bio-cybernetics model, correlation, physiology 


\section{Introduction}

A dairy cows farming is a very complex system (Bar-Yam 2003) consisting of several biological and economic factors (Baaijen et al. 1995). A system which would allow for analysis of interactions between all factors and their relationships would make it possible to describe the individual components of such system. Mathematical modeling (Murray 2002), econometric modeling (Green 2011) and computer simulation (Leon-Velarde et al. 2001, Bruijnis et al. 2010 ) are useful techniques to visualize from different perspectives various processes happening in such system. Models can be stochastic or deterministic and they are built to analyze and describe the implications of several components such as management, environment, nutrition, genetics, health, reproduction, etc. (Macciotta et al. 2005a, Bergman et al. 2012, Eastwood et al. 2012, Nguyen et al. 2013, Derks et al. 2014, Hansson et al. 2014, Murphy et al. 2014).

First mathematical model concerning dairy cattle was built in 1924, by Brody (Brody 1924, Brody et al. 1924) to describe lactation curves. Subsequently the comparison of different lactation curve models were described by several authors, among others (Silvestre et al. 2006, 2010, Cankaya et al. 2011) are worth mentioning. Mathematical analysis of milk production represents a very successful application of modeling systems in agriculture and animal breeding (Vargas et al. 2000, Macciotta et al. 2005b, Klop et al. 2013, Haile-Mariam et al. 2015). It is a valuable tool for development and validation of mechanistic models explaining features of milk production pattern. Mathematical programming is also a very useful tool for solving problems with optimization of dairy cows feeding (Janzekovic et al. 2014). In literature we can also find mathematical models describing udder infections caused by different bacteria such as Staphylococcus aureus or Brucella abortus (Lam et al. 1996, Nie et al. 2014). The applied models describe the relationship of milk production and health of dairy cows (Roche et al. 2009, Mantysaari et al. 2012, Tosi et al. 2012, Vergara et al. 2012), Vergara et al. 2014). This type of research is often associated with searching for the relationships between the blood test results and the welfare of dairy cows (Uden et al. 2008), (Matthews et al. 2012, Radkowska et al. 2014).

In this work we continued the above mentioned research trends and aimed to construct a digital model of a dairy cow. Cybernetics in the general sense is the science of control (Ross 1963, Wiener 1965). Its use, mainly in technical applications, results from the fact that if a cybernetic model of an object is being constructed, the relationships between various kinds of variables, that describe the model, are analyzed. Most frequently these variables are divided into the input variables, output variables and internal variables, describing the state of the object. During constructing a cybernetic model we should formally describe all the available characteristics and show the relationships between them mostly as a mathematical model in the form of algebraic equations, differential equations, etc. In effect it allows us to formulate the problem of object control, for example such as how to determine the input values to achieve the desired output characteristics of the test object. But it should be remembered that not always we know all the characteristics of the object that we want to control. Usually, that applies to the descriptions of the characteristics which define the internal state of the object. Then the constructed model is called a black box. Based on obtained measurement results of input and output characteristics, we can investigate the assumed functional form connected with input variables impact on the object. This allows, in the following stages of research, to formulate the problem of object control.

There is a natural question relating to whether the object of considerations in the construction of cybernetic model, and also the potential object of control, can be a live animal or even a group of animals of the same type. It is assumed that the study is connected with a herd of dairy cows, for which biochemical parameters and vital functions will be examined in order to create the basis for the construction of the cybernetic model of cow's organism. The research problem considered in this case, is to determine the identity of the quantitative and qualitative relationships between certain associations characterizing the process of breeding dairy cows in the herd. This could allow us to formulate some recommendations for cattle breeders and veterinarians regarding their activities in the process of cow's breeding in order to obtain satisfactory results in increased productivity, health and reproduction in dairy cow herds. In this problem of control it is assumed that we should follow the widely understood welfare of animals in the herd in the process of reproduction and breeding.

The intense regime of livestock farming subject dairy cows to numerous actions to maximize production effects, but the reaction of the cow's body under influence of these activities is not always positive. It can be said that indicators of the cow's welfare can be: their longevity, increasing milk production, reproductive efficiency, immunity, proper BCS, and even the behavior of the cows in contact with the supporting farm staff. Well targeted and motivated tasks for cattle breeders and veterinarians should help to increase production efficiency and food safety. 


\section{Materials and Methods}

It was assumed that the methodology for studying a dairy herd would include many various variables. One is the quality of fodder given to animals as it affects condition, productivity and health of the cows. This takes into account, among others, the content of dry matter, starch, protein, fiber ADF and NDF, ash and the size of the fodder. Moreover, the energy provided by the feed is affected, in addition to the mentioned above ingredients, by trace elements and vitamins.

The other analyzed factor is the environmental conditions, which are called the living conditions, and include temperature in the cowshed, humidity and the intensity of air movement, the type of stalls and bedding and free access to the feed. Another factor is the length of lactation, which depends not only on the lactation period, resulting from the reproductive cycles, but is also influenced by the farmer who decides to dry up the cow, which is the intended termination of lactation, so it is the control factor in the management processes connected with cows' body state.

It is worth to mention that lactation lasts from the date of delivery to the drying period and should last for about 305 days. Insemination time should also be considered as a typical input factor (control factor) for the model of cow organism because it is repeated regularly during the reproductive cycle. Another factor is the cowshed that is understood as certain features of the environment in which cow stays. It should be noted that this characteristic is associated not only with a single cow, but to a large extent, with the whole herd.

There is no doubt that the state of the cowshed has an impact on the condition of the animals in the herd and it can be presumed that it also has an influence on the reproductive parameters. The often overlooked factor when describing the herd is the knowledge of the herd owner. We can take into account the knowledge of the owner associated with vital processes of cows, physiological processes of vital cow's organs together with the environment, productivity as well as reproduction, as a cyclic factor affecting the production in the whole herd.

Among the factors having an impact on the cow condition, we can consider: cow's age, her pedigree, body conformation, the history of lactation, susceptibility to disease, and many others. In turn, the typical characteristics that describes the condition of the cow, including its welfare, we can include the quantity of milk received, evaluation of the milk quality, the number and state of calves, the parameters associated with cows reproductive process, including the length of the period from birth to successful insemination - IPP (Inter Pregnancy Period), from birth to birth - ICP (Inter Calving Period), the number of so called „open days" - from the first insemination after birth to successful insemination SP (Service Period) and insemination index, which is the number of inseminations necessary for single pregnancy.

As a novelty, it was decided to introduce additional factors of evaluating the condition of the cows in the herd. It is an analysis of acute phase proteins and sugars (and their derivatives) characterizing the welfare of cows on the basis of blood testing. Blood cells investigation (erythrocytes and leukocytes) provided the basis for an independent determination of the efficiency of glucose utilization in cow's body, glycolysis process and the usage of free fatty acids in the beta-oxidation processes in mitochondria of leukocytes. They describe the availability of the energy components in the feed for energy processes in the cow's body. Problems with availability are caused by improper feed composition or by destructive processes in the cow's body. It is an interesting characteristic obtained on the basis of specialized methods, which are generally not used in the daily cow's service. However, it will be used to obtain an independent evaluation of welfare in terms of energy (glycolysis, beta-oxidation), next to acute phase proteins (APP) in the investigated cows .

The study was performed on eleven lactating, Holstein-Fresian cows. Average age of evaluated cows was 1562 days (4,3 year). All animals were a part of a large herd (over 3500 cows), kept in the same conditions, in free stall barns, fed with TMR. Average milk yield was $9400 \mathrm{~kg}$ of milk per lactation. Number of lactations among examined cows ranged from 1 to 5 .

Blood samples were taken from jugular vein into EDTA-containing tubes, before parturition, in early lactation (0-1 month after calving) and 1-3 months after parturition. Samples were placed on ice and centrifuged $10 \mathrm{~min} 3000 \mathrm{~g}$. Obtained plasma was stored at $-80^{\circ} \mathrm{C}$ until insulin analysis. Insulin was assayed using Alpco Diagnostics ELISA-Kit for bovine insulin (NH, USA). This ELISA method is a sandwich-type immunoassay using mouse monoclonal antibodies specific for bovine insulin. The sensitivity of assay is 0.1 $\mathrm{ng} / \mathrm{ml}$ and within run variation is $3.5 \%$.

Erythrocytes (RBC) and Leucocytes (WBC) were separated by centrifugation of whole blood on the gradient of HISTOPAQUE-1077. RBC formed pellet, whereas WBC were located on the border of HISTOPAQUE/plasma. Cells were collected, washed twice with could PBS and resuspended in medium equal to initial volume of blood.

Value of glycolysis in red blood cells was estimated by estimation of glucose transport across cell 
Table 1. Examples of measurements of characteristics that describe the factors of the dairy cows in the herd.

\begin{tabular}{cccccccccc}
\hline Cows & $\begin{array}{c}\text { Age } \\
\text { (days) }\end{array}$ & $\begin{array}{c}\text { Number } \\
\text { of } \\
\text { lactation }\end{array}$ & $\begin{array}{c}\text { IPP } \\
\text { value } \\
(\text { days })\end{array}$ & $\begin{array}{c}\text { Average } \\
\text { feed } \\
\text { moisture } \\
(\%)\end{array}$ & $\begin{array}{c}\text { Average value } \\
\text { of the starch } \\
\text { in feed } \\
(\mathrm{g} / \mathrm{kg})\end{array}$ & $\begin{array}{c}\text { Average value } \\
\text { of protein in } \\
\text { feed } \\
(\mathrm{g} / \mathrm{kg})\end{array}$ & $\begin{array}{c}\text { Average value } \\
\text { of fiber ADF } \\
\text { protein in feed } \\
(\%)\end{array}$ & $\begin{array}{c}\text { Average value } \\
\text { of fiber NDF } \\
\text { protein in feed } \\
(\%)\end{array}$ \\
\hline 1 & 1324 & 2 & 88 & 36.4 & 19.5 & 12.6 & 25.2 & 44.8 \\
\hline 2 & 2463 & 5 & 199 & 35.3 & 19.6 & 13.5 & 25.3 & 42.5 \\
\hline 3 & 2018 & 4 & 122 & 36.1 & 20.1 & 13.9 & 24.3 & 41.8 \\
\hline 4 & 2232 & 5 & 151 & 39.1 & 19.5 & 13.8 & 24.5 & 40.6 \\
\hline 5 & 1618 & 3 & 162 & 40.4 & 19.6 & 14.7 & 24.1 & 40.1 \\
\hline 6 & 1155 & 2 & 178 & 44.5 & 21.3 & 13.3 & 22.5 & 40.4 \\
\hline 7 & 1571 & 3 & 87 & 43.9 & 21.7 & 13.6 & 13.8 & 21.8 & 38.6 \\
\hline 8 & 1099 & 2 & 98 & 34.2 & 19.3 & 13.9 & 24.8 & 41.2 \\
\hline 9 & 1095 & 2 & 448 & 34.9 & 20.4 & 13.6 & 25.3 & 40.5 \\
\hline 10 & 846 & 1 & 79 & 34.2 & 19.5 & 13.8 & 24.8 & 41.2 \\
\hline 11 & 1758 & 3 & 392 & 34.1 & 20.0 & & 40.9 \\
\hline
\end{tabular}

membrane. Uptake of $\left[{ }^{3} \mathrm{H}\right]$ deoxyglucose in erythrocytes incubated $10 \mathrm{~min}$ in HEPES solution was estimated using method described by Lee (Lee et al. 2000) with slight modification (Debski et al. 2011). After incubation of cells $(15 \mathrm{~min})$ with $0.1 \mu \mathrm{Ci}$ 2-deoxyglucose (Moravek Biochemicals Inc., CA, USA) RBC were centrifuged $10 \mathrm{~min}$ at $1000 \mathrm{~g}$, the pellet was washed with cold physiological saline, dissolved in $2 \mathrm{mmol} \mathrm{NaOH}$ and counted in Packard TriCarb scintillation counter.

Fatty acids degradation was examined in the leucocytes using the method of Manning et al. in modification of Kuryl et al. Cells were incubated $1 \mathrm{~h}$ with $0.1 \mu \mathrm{Ci}$ of $\left[9,10-{ }^{3} \mathrm{H}\right]$ palmitic acid (Moravek Biochemicals Inc., CA, USA) and after incubation samples were precipitated with $10 \%$ TCA and centrifuged for $10 \mathrm{~min}$ at $2000 \mathrm{~g}$. Supernatant was collected, alkalized and passed through column of Bio-Rad AG-1 X8 ionic exchange resin (Bio-Rad Hercules, CA, USA). Effluent containing tritiated water was counted in Packard TriCarb scintillation counter. Results were expressed as pmol of palmitic acid decomposed per $\mathrm{mg}$ of leucocyte protein during $1 \mathrm{~h}$.

Acute Phase Proteins (APP) levels in blood serum were evaluated using ELISA commercial kits: bovine C-reactive protein, bovine Fibrinogen and bovine Haptoglobin produced by GenxBio Health Sciences Pvt. Ltd. (Delhi, India).

The study of the relationship between the above-mentioned factors is related to several goals:

- determine the significance of these factors in the constructed model,

- investigation of the correlation between input variables, describing a herd of dairy cows, with variables describing animal welfare,
- investigation of the correlation between factors, that describe animal welfare.

In this study the methods of correlation coefficients analysis were used. This will indicate the input factors, which are strongly correlated with variables evaluating the herd, and at the same time weakly correlated with each other. They should be included in the described model. The Hellwig method was also used, takes all the potential input variables and creates all possible combinations, then testing integral capacity of information connected with each combination. Therefore, in the impact of using each of the possible combinations on the model's accuracy is analyzed. In this way, we obtain an optimal set of input variables, being concerned, while minimizing the number of used variables which has a positive effect on the size of the model.

\section{Results}

Multi-equations model with multiple input variables has been constructed that evaluate many factors which describe herd of dairy cows. This model to a certain degree of generality has following form:

$$
y_{k t}=f_{t}\left(x_{1 t}, x_{2 t} \ldots, x_{m t}, \xi_{k}\right), t=1, \ldots, T, k=1, \ldots, K
$$

where

$y_{k t}-$ result of measurement number $t$ of the output variable number $k$ evaluating the welfare of cow herd,

$x_{i t}-$ result of measurement number $t$ of the input variable number $i(i=1, \ldots, m)$,

$\xi k$ - random component present in the description of output variable number $k$, 
Table 2. Examples of measurement of WBC $\beta$-oxidation, glucose transport through RBC membranes, plasma insulin and acute phase proteins (CRP, Fibrinogen, Haptoglobin) of dairy cows in the herd.

\begin{tabular}{ccccccc}
\hline Cows & $\begin{array}{c}\beta \text {-oxidation } \\
\text { pmol/min/mg }\end{array}$ & $\begin{array}{c}\text { Glucose } \\
\mu \text { mol/h/g }\end{array}$ & $\begin{array}{c}\text { Insulin } \\
\mu \mathrm{g} / \mathrm{l}\end{array}$ & $\begin{array}{c}\mathrm{CRP} \\
\mathrm{mg} / \mathrm{l}\end{array}$ & $\begin{array}{c}\text { Fibrinogen } \\
\mathrm{g} / \mathrm{l}\end{array}$ & $\begin{array}{c}\text { Haptoglobin } \\
\mathrm{mg} / \mathrm{l}\end{array}$ \\
\hline 1 & 13.89 & 54.75 & 1.03 & 1.024 & 5.01 & 1.32 \\
\hline 2 & 12.13 & 27.01 & 0.97 & 0.983 & 4.03 & 1.145 \\
\hline 3 & 11.28 & 31.55 & 0.8 & 0.942 & 4.26 & 1.398 \\
\hline 4 & 23.89 & 33.39 & 0.87 & 1.023 & 5.77 & 1.178 \\
\hline 5 & 40.4 & 51.87 & 0.89 & 1.024 & 5.1 & 1.33 \\
\hline 6 & 16.03 & 31.89 & 0.87 & 0.902 & 3.86 & 1.359 \\
\hline 7 & 14.97 & 36.1 & 0.92 & 1.024 & 6.03 & 1.438 \\
\hline 8 & 5.75 & 57.19 & 1.92 & 1.146 & 7.23 & 1.044 \\
\hline 9 & 28.05 & 52.27 & 1.1 & 1.349 & 5.77 & 1.349 \\
\hline 10 & 7.03 & 36.96 & 0.88 & 1.146 & 6.34 & 1.145 \\
\hline 11 & 15.6 & 40.64 & 1.12 & 0.983 & 4.74 & 1.459 \\
\hline
\end{tabular}

$t$ - number of the next measurement (observation),

$m$ - the number of input variables,

$T$ - number of measurements,

$K$ - the number of output variables, evaluating the welfare of the cow herd.

During the measurements we obtained values of factors characterizing the several parameters evaluation for individual dairy cows in cow herd. To illustrate the obtained results we show below results for the selected cows from a cow herd. The first table (Table 1) contains measurements of typical factors characterizing dairy cows in herds.

The following table (Table 2) contains measurements of $\beta$-oxidation in WBC, glucose (glucose transportation across RBC membranes), acute phase proteins $(\mathrm{C}$ - reactive protein, Fibrinogen, Haptoglobin) and insulin in the blood plasma of dairy cows for the tested cows in the herd.

In order to explain the contents of the Table 2 it is worth to add that $\mathrm{C}$-reactive protein (CRP) is a protein belonging to the so called acute phase proteins. The same group of proteins contains also haptoglobin and fibrinogen. Haptoglobin ( $\mathrm{Hp}$ ) in turn, is an acute phase protein which is responsible for the uptake of free hemoglobin in the blood.

They are non-specific inflammation markers and can be used in the evaluation of an individual cow, as well as a heard health status, and also for early disease surveillance.

Fibrinogen, which is a fibrin precursor, takes also part in localization of tissues in which inflammatory process takes place. The $\beta$-oxidation is a number of reactions in the conversion of fatty acids into acetyl-coenzyme A.
As a result of the study, with the model following parameters has been adopted (from the point of view of their variation): the number of days for effective insemination (AI), moisture feed, the age of the cows, the number of lactation, beta-oxidation in $\mathrm{WBC}$, transport of glucose in $\mathrm{RBC}$ (strong relation with efficacy of glycolysis, insulin level, CRP and fibrinogen level). In turn, following parameters are rejected from the model (because of their low variance measurements): the amount of starch in the feed, the amount of protein in feed, fiber fraction NDF and ADF in the feed and the level of haptoglobin in the blood.

As the first relationship we can specify dependence between the number of days to the effective insemination (AI) and the length of ICP. This dependence is important and with the increase in the number of days for effective AI increases the length of ICP. This result is shown in the Fig. 1.

The dependence of number of days to effective insemination (AI) with respect to the ICP, except for some random results, is linear, since the quadratic argument obtained from the calculation is negligibly small:

$$
y=0.0005 \cdot x^{2}+0.6909 \cdot x+335,17
$$

where ,y" is the number of days to effective insemination AI, $\mathrm{x}$ - the length of ICP. Thus, there is actually:

$$
\mathrm{y}=0.6909 \cdot \mathrm{x}+335.17
$$

It can be seen that the number of days to effective insemination $\mathrm{AI}$ increases with the length of time between calving ICP. 


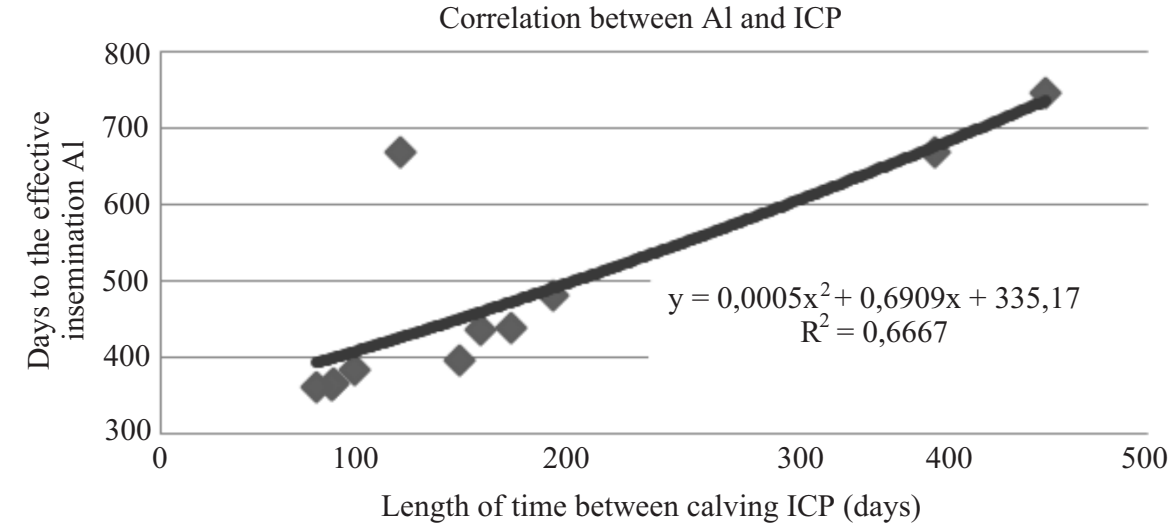

Fig.1. The results of the dependence between the number of days to effective AI and ICP.

Dependence between the humidity level of feed and ICP

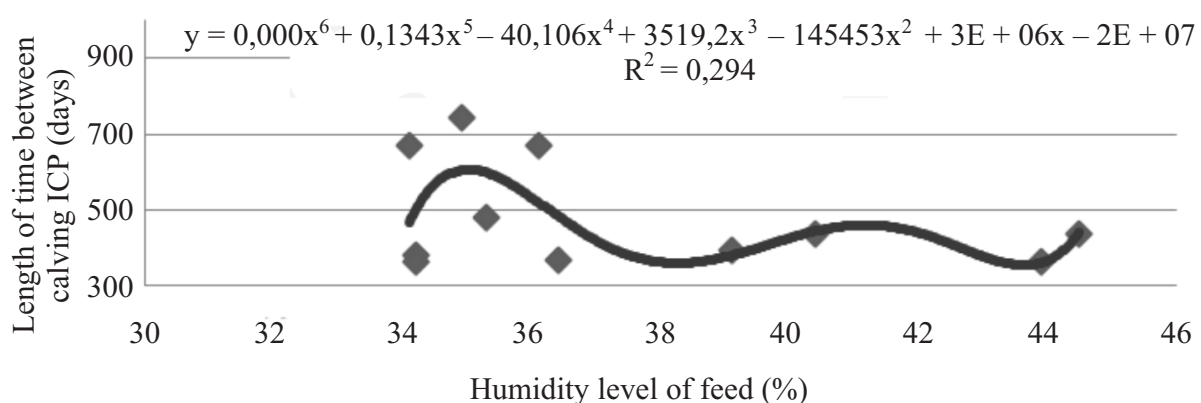

Fig. 2. The results of the dependence between the humidity level of feed and ICP.

Dependence between the age of cows and the length of the lactation

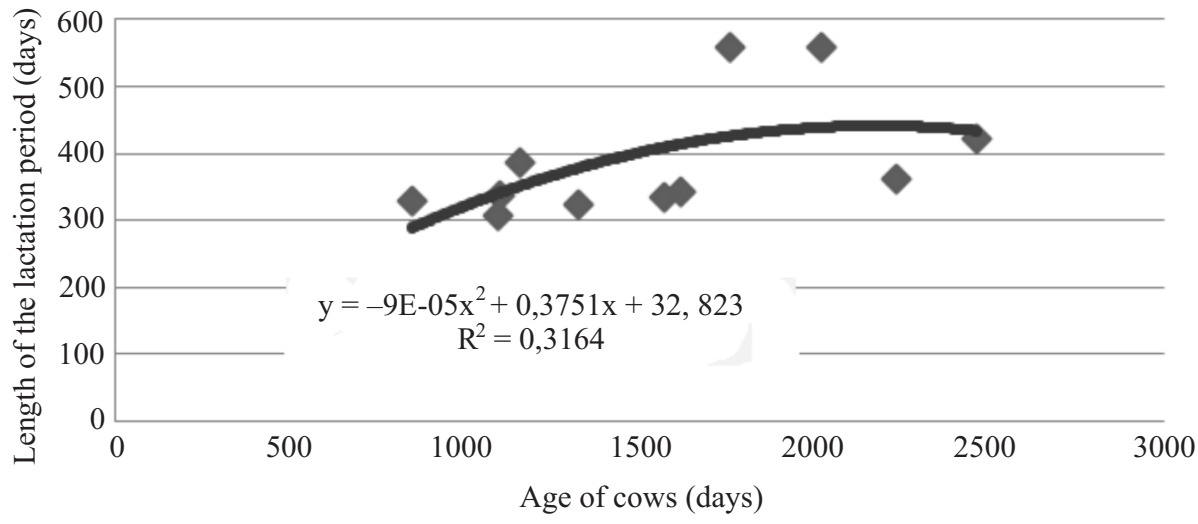

Fig. 3. The results of the dependence between the age of cows and the length of the lactation period OL.

In turn, the results of the correlation research between the humidity level of feed and length of time between calving ICP are shown in the Fig. 2 .

In this case, the relationship is not so easy to describe using a linear function. Its formula is as follows:

$$
\begin{gathered}
y=0.0006 \cdot x^{6}+0.1343 \cdot x^{5}-40.106 \cdot x^{4}+3519.2 \cdot x^{3}- \\
-145453 \cdot x^{2}+3 E+06 \cdot x-2 E+07
\end{gathered}
$$

Moisture level of feed given to the herd fluctuates around a certain value for changing the length of time between calving ICP.

An interesting relationship was found between the age of cows and the length of the lactation period (OL). This result is shown in Fig. 3.

This dependence could be described by using polynomial function. Its formula is as follows:

$$
y=-9 E-05 \cdot x^{2}+0.3751 \cdot x+32.823
$$




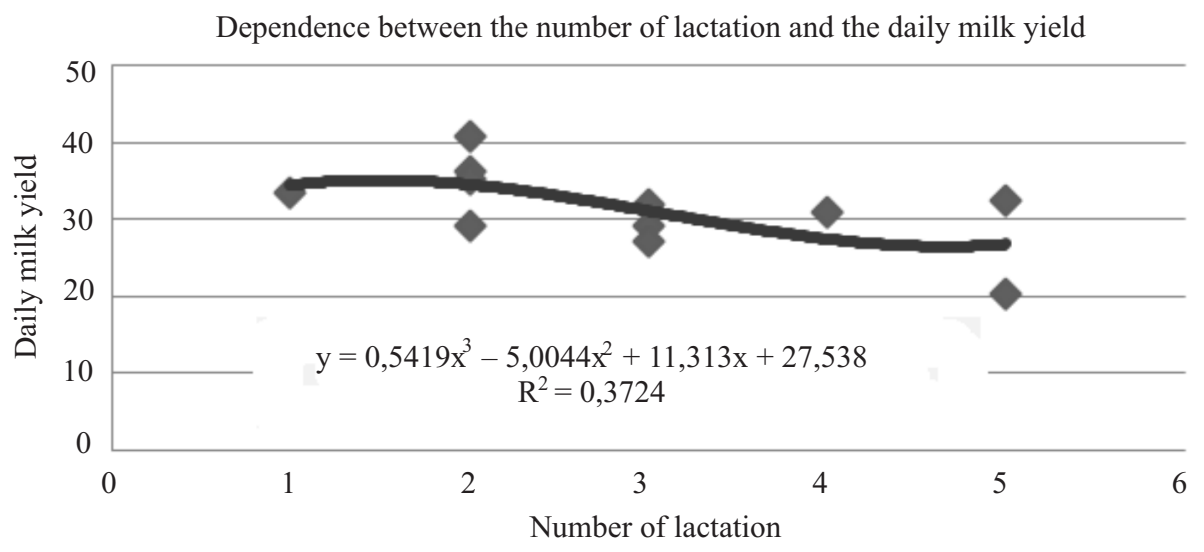

Fig. 4. The results of the dependence between the number of lactation and the daily amount of received milk.

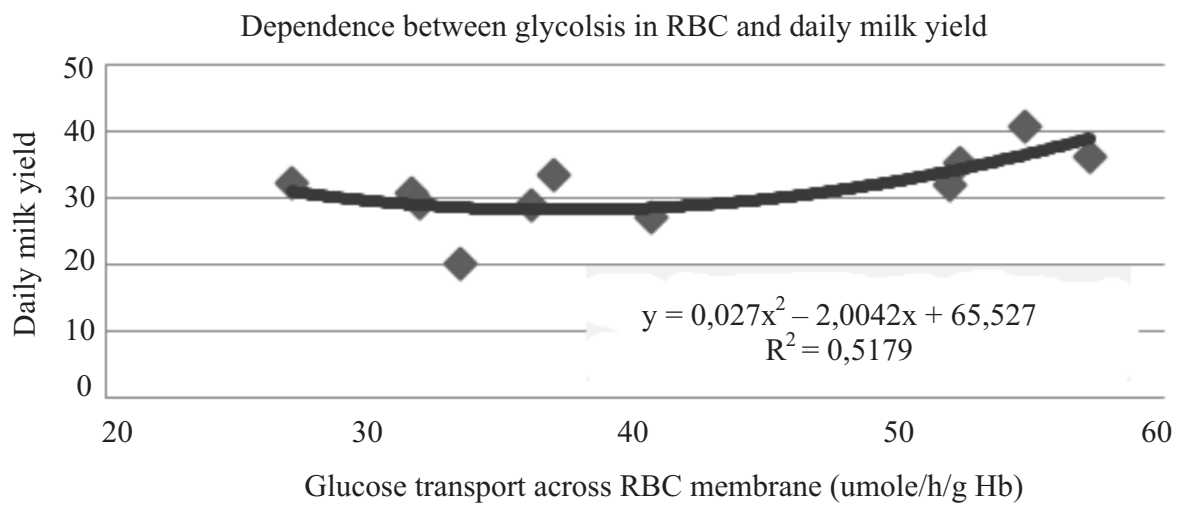

Fig. 5. The results of the dependence between level of glucose transport across RBC membrane and daily milk yield.

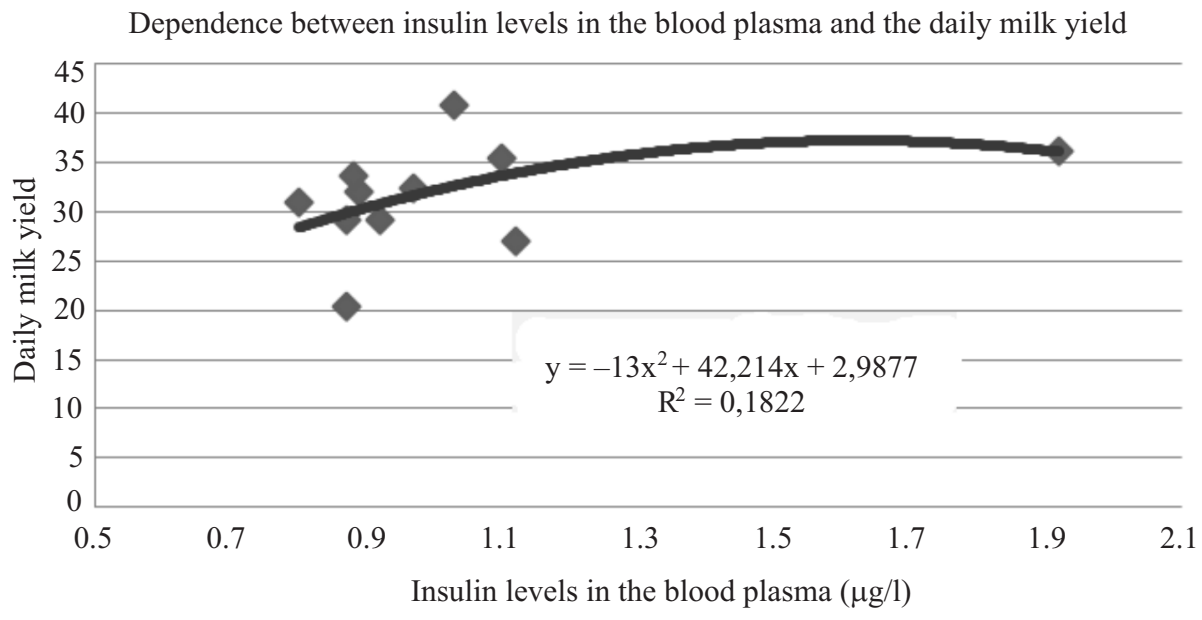

Fig. 6. The results of the dependence between insulin levels in the blood plasma of cows and the daily amount of received milk.

The length of lactation period for herd increased with the age of the cows in this herd. Similarly, an interesting relationship between the number of lactation and the daily milk yield was found. This result is shown in Fig. 4.

This dependence can be described by using polynomial function. Its formula is as follows:

$$
\mathrm{y}=0.5419 \cdot \mathrm{x}^{3}-5.0044 \cdot \mathrm{x}^{2} 11.313 \cdot \mathrm{x}+27.638
$$

The level of the daily amount of received milk in the herd is decreasing slightly with changing the number of lactation in cows in the herd.

In turn, relation between level of glucose transport across RBC membranes and daily amount of received milk had the form as shown in Fig. 5. 


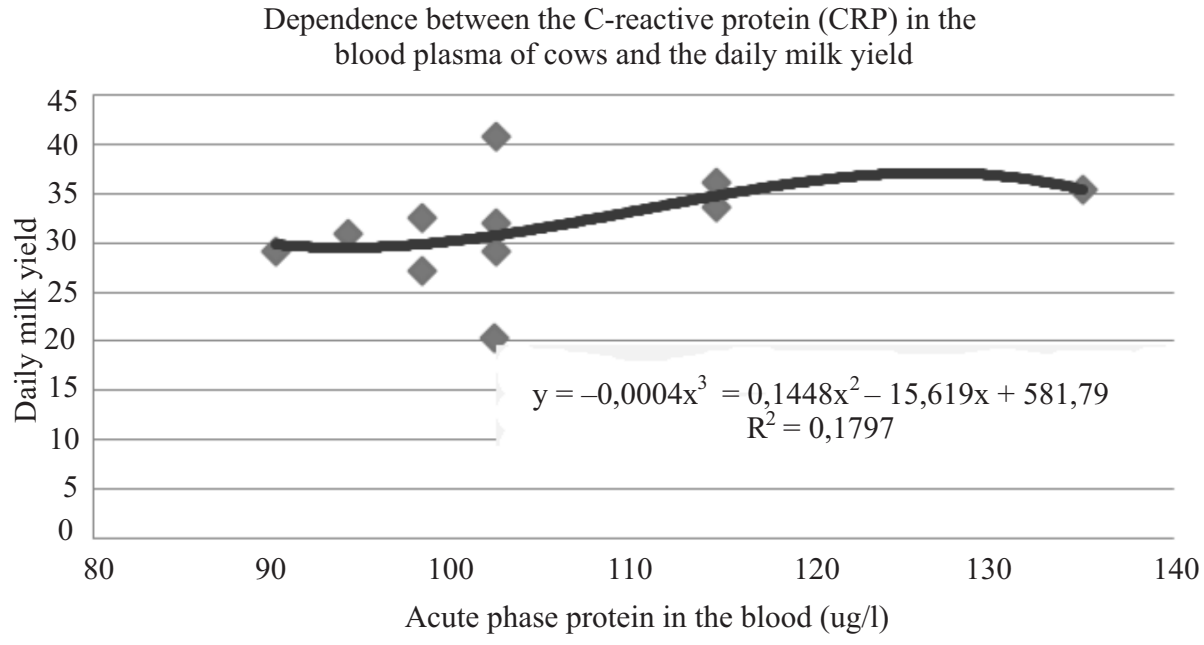

Fig. 7. The results of the dependence between the acute phase protein in the blood of cows and the daily amount of received milk.

Dependence between CRP level and the length of lactation period OL

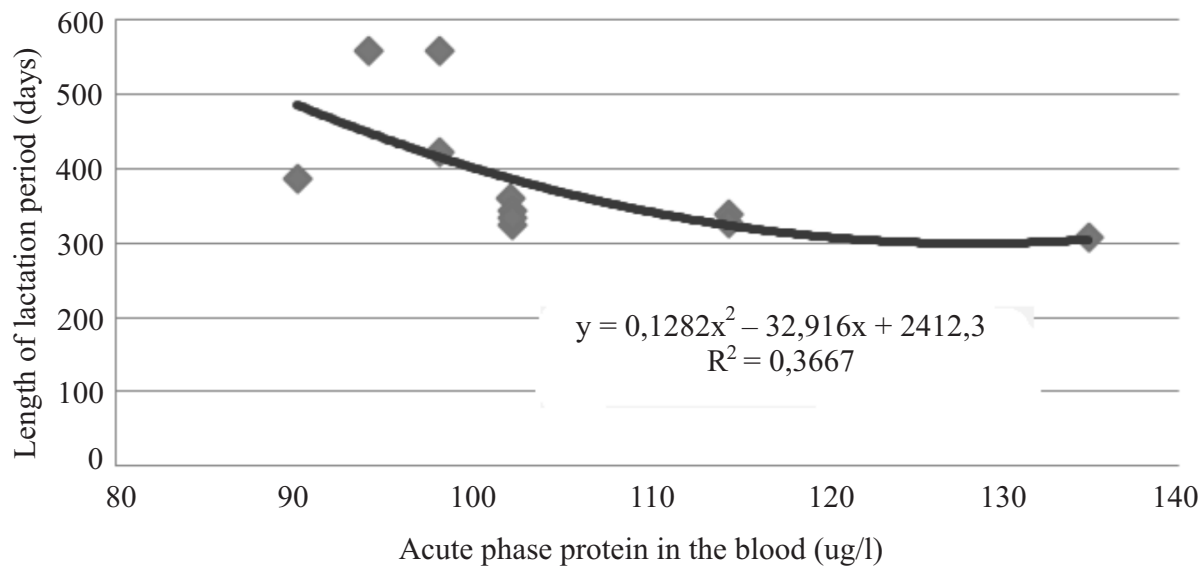

Fig. 8. The results of the dependence between the acute phase protein in the blood plasma of cows and the length of lactation period OL.

This dependence can be described by using polynomial function. Its formula is as follows:

$$
\mathrm{y}=0.027 \cdot \mathrm{x}^{2}-2.0042 \cdot \mathrm{x}+65.527
$$

The level of the daily amount of received milk in the herd increases slightly with changing glucose levels in the blood of cows in the herd.

Also the relationship between insulin levels in the blood plasma of cows and the daily amount of received milk was examined. This dependence is shown in Fig. 6.

This relationship can be described by using polynomial function. Its formula is as follows:

$$
\mathrm{y}=-13 \cdot x^{2}+42.214 \cdot x+2.9877
$$

The level of daily amount of received milk in the herd grows slightly for changing the level of insulin in the blood of cows in the herd.
Also the relationship between the acute phase protein in the blood of cows and the daily milk yield was examined. This formula is shown in Fig. 7.

This dependence can be described by using polynomial function. Its formula is as follows:

$$
y=-0.0004 \cdot x^{3}+0.1448 \cdot x^{2}-15.62 \cdot x+581.79
$$

The level of the daily amount of received milk in the herd grows slightly for changing the level of CRP in the blood of cows in the herd.

In turn, the relationship between CRP level and the length of lactation period OL of cows in the herd is shown in Fig. 8.

This dependence can be described by using polynomial function. It is formula is as follows:

$$
y=0.1282 \cdot x^{2}-32.916 \cdot x+2412.3
$$


The length of lactation period of cows in the herd decreases for varying levels of the acute phase protein CRP in the plasma of cows in the herd.

Apart from examining the correlation between different parameters describing the cows in the herd, we constructed bio-cybernetic model of cows. In this case, the parameters describing the cow in the herd, after their determination of the variance, are as follows: the number of days to effective insemination AI, level of protein in the feed, the age of the cows in the herd, the number of lactation for cows and the level of $\beta$-oxidation, glucose transmembrane transportation and plasma insulin. Consecutive numbers are assigned to the variables listed above. As the characteristics that describe the welfare of animal we adopted to study: the daily amount of received milk, the length of the OL (lactation period) and the length of ICP.

As a result of the calculation we obtained the formulas of the linear model in the form of three equations shown below:

$$
\begin{aligned}
& y_{1}=4.49-0.0086 \cdot x_{1}+0.98 \cdot x_{2}+0.0063 \cdot x_{3}- \\
& -3.3035 \cdot x_{4}+0.1215 \cdot x_{5}+0.0287 \cdot x_{6}+9.4955 \cdot x_{7} \\
& y_{2}=213.9+0.46 \cdot x_{1}+0.05 \cdot x_{2}+0.18 \cdot x_{3}- \\
& -56.32 \cdot x_{4}-1.13 \cdot x_{5}+0.07 \cdot x_{6}+21.23 \cdot x_{7} \\
& y_{3}=275.94+1.04 \cdot x_{1}+0.45 \cdot x_{2}+0.02 \cdot x_{3}+ \\
& +4.5 \cdot x_{4}-0.08 \cdot x_{5}+0.15 \cdot x_{6}+0.84 \cdot x_{7}
\end{aligned}
$$

where

$y_{1}$ - daily amount of received milk,

$y_{2}$ - length of lactation period OL for cows in the herd,

$y_{3}$ - the length of ICP for cows,

$x_{1}$ - the number of days to effective insemination AI,

$x_{2}$ - the amount of protein in the feed,

$x_{3}$ - the age of the cows,

$x_{4}$ - the number of lactating cows,

$x_{5}-$ the level of $\beta$-oxidation,

$x_{6}$ - glucose transport level,

$x_{7}$ - plasma insulin levels.

For each equations we obtained values of the determination coefficient $\mathrm{R}^{2}$ defining the quality of the obtained relationship, having a value from interval [0.1]. For the first equation determination coefficient is 0.32 , for the second equation is 0.68 , while for the third is 0.99. In effect we obtained the result as the relationship between the input variables, describing the parameters of cows with output variables, describing their welfare. The level of determination coefficients obtained for the equations is good enough, acceptable in this type of research for the application of mathematical modeling.

\section{Discussion}

The results of this study allowed us to conclude that modern diagnostics, stimulated by progress in the life sciences and information technology with monitoring interdependence of life events of cow and its environment, will increase animal welfare and will improve the economic effects. Animal welfare is also related to the composition and preparation of feed, technology of nutrition and milking (caused by newer milking systems).

Such changes stimulated cows' positive response. However, it does not mean the decrease of health problems when the cows are subjected to a considerable strain: lactation performance and pregnancies in a particular regime dictated by economic profitability. There is also a big difference between farms established in 80's/90's and modern ones due to modern technology and management solutions. For example, in the older farms cow's injuries caused by bad construction of facilities were much more common.

Listed agents positively correlated with economic effect, i.e.: milk yield, reduction in treatment costs and improve the welfare and parameters, such as $\beta$-oxidation, glycolysis, acute phase proteins (APP) - C - reactive protein, fibrinogen and haptoglobin.

The results were evaluated statistically. Correlation of selected biochemical parameters of body fluids with evaluation of herd's indices, reproduction and fertility indices and composition of milk and feed (including dry period) was established. Issues of technology on dairy farms are the infrastructure and technology, equipment and procedures. Veterinary services on farms similarly await a statistical evaluation of the procedures' effectiveness. This study is just a part of evaluated factors and requires further scientific investigation of all the process on dairy farms.

The assumptions presented here and methodology of research in relation to veterinary health care of cows on farms are innovative. Maximizing the effects of production in cow herd was positive only in a certain period of time (3 to 4 lactation). Desirable positive signals from cows are: longevity, increasing milk production, reproductive efficiency, resistance to care, proper BCS and the behavior of cows in relation to staff farms.

Cybernetic model of a cow as a tool for practitioners and analysts, helps them to increase the production efficiency of cows and increase the scope and effectiveness of tasks performed by a veterinarian. It helps to increase the food security and supply arguments to evaluate and improve welfare. Coefficients of $\beta$-oxidation, glycolysis and acute phase proteins: $\mathrm{C}$ - reactive protein, Fibrinogen and Haptoglobin are sufficient, individual for each cow, factors evaluating 
its welfare. The use of protocols describing veterinary handling, such as hormone or antibiotic treatment, expect statistical evaluation of these procedures efficacy. Coefficients of $\beta$-oxidation, glycolysis and acute phase proteins $(\mathrm{C}-$ reactive protein, Fibrinogen and Haptoglobin), individual for each cow, are sufficient factors for evaluating cow's welfare.

It is worth to underline that the presented model is relevant for the measurements obtained in the investigated, single dairy herd. Results may differ for other herds, depending on the herd management, environment, care and veterinary routine etc. Extending the research on larger population of dairy cows in the country would allow the determination of the characteristics relevant to a broader research.

\section{Acknowledgements}

This work was supported by Grant for Scientific Research from the National Science Centre (NN308576640).

\section{References}

Baaijen M, Pérez E (1995) Information technology in the Costa Rican dairy sector: A key instrument in extension and on-farm research. Agric Hum Values Volume 12: $45-51$

Bar-Yam Y (1997) Dynamics of Complex Systems. Addison Wesley.

Bergman MA, Richert MR, Cicconi-Hogan KM, Gamroth MJ, Schukken YH, Stiglbauer KE, Ruegg PL (2012) Comparison of selected animal observations and management practices used to assess welfare of calves and adult dairy cows on organic and conventional dairy farms. J Dairy Sci 97: 4269-4280

Brody S (1924) The kinetics of senescence. J Gen Physiol 6: $245-257$

Brody S, Turner CW, Ragsdale AC (1924) The relation between the initial rise and the subsequent decline of milk secretion following parturition. J Gen Physiol 6: 541-545.

Bruijnis MR, Hogeveen H, Stassen EN (2010) Assessing economic consequences of foot disorders in dairy cattle using a dynamic stochastic simulation model. J Dairy Sci 93: 419-2432.

Cankaya S, Unalan A, Soydan E (2011) Selection of a mathematical model to describe the lactation curves of Jersey cattle. Archiv Tierzucht 54: 27-35.

Derks M, Hogeveen H, Kooistra SR, Van Werven T, Tauer LW (2014) Efficiency of dairy farms participating and not participating in veterinary herd health management programs. Prev Vet Med 117: 478-486.

Debski B, Kuryl T, Gralak MA, Pierzynowska J, Drywien $M$ (2011) Effect of inulin and oligofructose enrichment of the diet on rats suffering thiamine deficiency. J Anim Pysiol Anim Nutr 95: 335-342.
Eastwood CR, Chapman DF, Paine MS (2012) Networks of practice for co-construction of agricultural decision support systems: Case studies of precision dairy farms in Australia. Agr Syst 108: 10-18.

Green WH (2011) Econometric analysis, Prentice Hall 2003.

Haile-Mariam M, Pryce JE (2015) Variances and correlations of milk production, fertility, longevity, and type traits over time in Australian Holstein cattle. J Dairy Sci 98: 7364-7379.

Hansson H, Lagerkvist CJ (2014) Decision Making for Animal Health and Welfare. Integrating Risk-Benefit Analysis with Prospect Theory. Risk Anal 34: 149-1159.

Janzekovic M, Rozman C, Pazek K, Pevec P (2014) Mathematical model for balancing feed rations in dairy cow. In: Katalinic B (ed) DAAAM International Scientific Book, pp 153-162.

Klop G, Ellis JL, Bannink A, Kebreab E, France J, Dijkstra $\mathrm{J}$ (2013) Meta-analysis of factors that affect the utilization efficiency of phosphorus in lactating dairy cows. J Dairy Sci 96: 3936-3949.

Kuryl T, Adamowicz M, Debski B, Bertrandt J, Martynik K (2001) Degradation of $[9,10]-{ }^{3} \mathrm{H}-$ myristic acid by lymphocytes. Screening test of inherited disorders of activation, transport and mitochondrial oxidation of fatty acids. Atheroskleroza 5: 23-27.

Lam TJ, DeJong MC, Schukken YH, Brand A (1996) Mathematical Modeling to estimate efficacy of postmilking teats disinfection in split-udder trials of dairy cows. J Dairy Sci 79: 62-70.

Lee DN, Yen HT, Shen TF, Chen BJ (2000) Chromium-induced glucose uptake, superoxide anion production and phagocytosis in cultured pulmonary alveolar macrophages of weanling pigs. Biol Trace Elem Res 77: 53-64.

Leon-Velarde CU, Quiroz R (2001) Modeling cattle production systems: integrating components and their interactions in the development of simulation models. In: Proceedings - Third International Symposium on Systems Approaches for Agricultural Development, Lima Peru. p 18.

Macciotta NP, Dimauro C, Rassu SP, Steri R, Pulina $\mathrm{G}(\mathbf{2 0 0 5}, \mathbf{a})$ The mathematical description of lactation curves in dairy cattle. Ital J Anim Sci 10: e51.

Macciotta, NPP, Vicario, D, Cappio-Borlino A $\mathbf{( 2 0 0 5 , ~ b ) ~}$ Detection of different shapes of lactation curve for milk yield in dairy cattle by empirical mathematical models. J Dairy Sci 88: 1178-1191.

Manning N.J., Olpin S.E., Pollitt R.J., Webley J.: A comparison of $\left[9,10-{ }^{3} \mathrm{H}\right]$ palmitic and $\left[9,10-{ }^{3} \mathrm{H}\right]$ myristic acid for the detection of defects of fatty acid oxidation in intact cultured fibroblast. J Inherited Metab Disease 13: 58-68.

Mantysaari P, Mantysaari E (2012) Modeling of daily body weights and body weight changes of Nordic Red cows. J Dairy Sci 98: 6992-7002.

Matthews LR, Cameron C, Sheahan AJ, Kolver ES, Roche JR (2012) Associations among dairy cow body condition and welfare-associated behavioral traits. J Dairy Sci 95: 2595-2601.

Murphy MD, O'Mahony MJ, Shalloo L, French P, Upton J (2014) Comparison of modeling techniques for milk-production forecasting. J Dairy Sci 97: 3352-3363.

Murray JD (2002) Mathematical Biology I: An Introduction. Springer-Verlag. 
Nguyen TT, Doreau M, Corson MS, Eugene M, Delaby L, Chesneau G, Gallard Y, van der Werf HM (2013) Effect of dairy production system, breed and co-product handling methods on environmental impacts at farm level. J Environ Manag 120: 127-137.

Nie J, Sun G-Q, Sun X-D, Zhang J, Wang H (2014) Modeling the transmission dynamics of dairy cattle brucellosis in Jilin province, China J Biol Syst 22: 533-535.

Radkowska I, Herbut E (2014) Hematological and biochemical blood parameters in dairy cows depending on the management system. Anim Sci Pap Rep 32: 317-325.

Roche JR, Friggens NC, Kay JK, Fisher MW, Stafford KJ, Berry DP (2009) Invited review: Body condition score and its association with dairy cow productivity, health, and welfare. J Dairy Sci 92: 5769-5801.

Ross AW (1963) An Introduction to Cybernetics, John Wiley \& Sons Silvestre AM, Petim-Batista F, Colaco J (2006) The accuracy of seven mathematical functions in modeling dairy cattle lactation curves based on test-day records from varying sample schemes. J Dairy Sci 89: 1813-1821.
Silvestre AM, Almeida JC, Santos VA, Fontes PJ, Alves VC (2010) Modeling lactation curves of „Barrosa” beef cattle with Wood's model. Ital J Anim Sci 9: 244-247.

Tosi MV, Canali E, Gregoretti L, Ferrante V, Rusconi C, Verga M, Carenzi C (2012) A Descriptive Analysis of Welfare Indicators Measured on Italian Dairy Farms: Preliminary Results. Acta Agric Scand Sect A - Animal Sci (Suppl 30): 69-72.

Uden P, Danfaer A (2008) Modeling glucose metabolism in the dairy cow. A comparison of two dynamic models. Anim Feed Sci Technol 143: 59-69.

Vargas B, Koops WJ, Herrero M, Van Arendonk JA (2000) Modeling extended lactations of dairy cows, J Dairy Sci 83: 1371-1380.

Vergara CF, Döpfer D, Cook NB, Nordlund KV, McArt JAA, Nydam DV, Oetzel GR (2014) Risk factors for postpartum problems in dairy cows: Explanatory and predictive modeling. J. Dairy Sci. 97: 4127-4140.

Wiener N (1965) Cybernetics or the control and communication in the animal and the machine. MIT Press. 